\title{
13
}

\section{Socialization of Language and Morality at Chinese Christian Church of Berlin}

\author{
Jingyang Yu
}

I first came across members of the Chinese Christian Church of Berlin (CCCB) in November 2010. Within a month of arriving in Berlin as a student, members of the CCCB approached me on the university campus and the students' dormitory on three separate occasions. Two of them came up to me in the students' cafeteria, handing out pamphlets about Christianity and Jesus and inviting me to go to their church on Sunday. The third approach was from a friendly neighbour in the dorm, who asked me to join her and her friends for dinner later that Friday evening to 'have some fun'.

Attracted by my own imagination of what a fun Friday night might be like, I went to dinner with my neighbour and her friends, which turned out to be a meeting of their Bible group. It took place in a Chinese acupuncture and massage centre in Prenzlauer Berg that was owned by two members of the group. Fifteen people were present that evening, including a few students like myself. The majority of group members, either employees of

\footnotetext{
J. Yu $(\bowtie)$

Max Planck Institute for the Study of Religious and Ethnic Diversity, Göttingen, Germany e-mail: yujingyang@outlook.com 
companies or owners of their own businesses, were between thirty and forty years old. The meeting lasted for five and a half hours and included Bible reading, general and small-group discussions, singing gospel songs, praying and dinner, which all the members referred to as a 'feast of Love' (爱宴). At the end of the evening, the groups sat together in a circle, with closed eyes and firm grips on each other's hands, and shouted my name together in their prayers. They called out my name and 'Hallelujah' repeatedly, thanking God for leading me to this meeting tonight, asking Him to have mercy on me and begging Him not to give up on me:

'God, Jingyang is an innocent child! She did not know she was a sinner!' 'She didn't know!'

'She did not know she has to go to hell!'

'She didn't know!'

'Hallelujah!' several voices shouted together.

'Please forgive her ignorance and give her another chance! Please, my Father in Heaven!'

'Hallelujah!'

'Save Jingyang!', 'Save Jingyang!' Almost all of them chanted together. 'Amen!'

A fun Friday night indeed.

I was determined to come to terms with what I had experienced that Friday night. I started attending the CCCB's Sunday service and conducted fieldwork with three different Bible groups in different parts of the city in November 2011-February 2012, September-December 2012, January-March 2014 and August 2015-July 2016.

This chapter starts with a brief introduction to the CCCB before describing the unique demographic characteristics of the congregation compared to other Chinese Christian churches in Germany. It presents extensive ethnographic data in the following two sections, where it analyses the motivations of the first-generation Chinese immigrants in taking their children to the church and the strategies the church leadership pursue in meeting the needs and wishes of its members. Besides highlighting Chinese language and identity, the final section shows how the CCCB also provides Chinese migrant families with a space in which to construct 
shared codes of morality and thus institute the socialization of that morality at a religious institution.

\section{The Chinese Christian Church of Berlin}

During my fieldwork, there were two Chinese Protestant churches in Berlin: the CCCB with which I began this chapter, and the Chinese Alliance Church of Berlin (CACB). Starting out as an informal Bible group of seven students in West Berlin in the 1980s, the CCCB has grown into the largest Chinese Christian congregation in Germany in recent decades, especially since the Rutgers Community Christian Church (RCCC), a Chinese Christian church in New Jersey, USA, began providing it with financial and personnel support in 1999. Since 2006, the CCCB has rented the church building of the Protestant Church at Hohenzollernplatz (Evangelische Kirchengemeinde am Hohenzollernplatz) in the southwest of the city, where they hold their weekly service every Sunday afternoon and 'an evening of worship' every Thursday evening.

Chinese Christians in both China and the diaspora tended to call Catholicism 'Catholicism' (天主教) and Protestantism 'Christianity' (基督教). Members of the CCCB considered themselves to be 'Christians' (基督徒), while many of them enjoyed drawing a sharp distinction between the Catholics and themselves during their discussions. Pastor $\mathrm{Xu}$, who had been preaching at the CCCB since 2006, was baptized in a Baptist Church in Taiwan. The RCCC and CCCB both had strong theological objections to infant baptism and offered full-immersion baptism to adults only. However, Pastor Xu and members of the CCCB Church committee refused to be associated with the Baptist denomination. Instead, they emphasized repeatedly, the CCCB was 'an independent church', 'a Christian church' that did not belong to any denomination.

Währisch-Oblau (2005) and Gotthard Oblau $(2006,2011)$ have analysed the establishment of Chinese Protestant churches in Germany and point out that most of these churches exist in the form of 'Freikirchen' (free churches) within the German categorization of church institutions. Most Chinese Protestant churches in Germany, like the CCCB and $\mathrm{CACB}$, were founded and supported by mission-oriented institutions in 
countries outside Germany, typically in the US, and often share an unreserved focus on missionary work. The CACB, the second Chinese Christian church in Berlin, was founded in 2006 by 'the Christian and Missionaries Alliance' (C\&MA) with personnel and funding directly from the US. By 2015, the C\&MA, an American evangelical denomination with more than six million members in seventy countries, had established two Chinese Christian churches in Germany.

\section{Students Leave, Families Come}

Being the largest Chinese Christian congregation in Germany, the CCCB had roughly 250 members at the time of my fieldwork, about 180 to 200 of whom attended church services on Sundays. ${ }^{2}$ Compared to the German 'Landeskirchen', the CCCB had much less interest in collecting accurate data about its members. Neither the pastor nor the church committee was able to provide any precise demographic data for their community. During the Christmas service on 24 December 2012, Pastor Xu announced that there were around 250 members of the Church, of whom a third were under the age of 25. My impression during participant observation was that this figure was roughly correct. A regular Sunday service usually attracted around 100 to 120 adults and 60 to 80 children.

Since 2000, German universities have undergone a series of reforms, including offering more studies and programmes to meet the needs of international students. The increasing number of courses in English and the separation of Bachelor's and Master's Studies, for example, has made it easier for foreigners outside Germany to become students at German universities. At the same time, more 'agents for education abroad' (留学 中介) have opened for business in China, offering an application advice service for Chinese students wishing to enter German universities and colleges. These additional incentives enhanced the popularity of Germany as a destination for Chinese students, whose number quintupled from 1999 to 2004. Since 2004, Chinese students have become the largest group of foreign students in Germany. By the end of 2015, 38,833 Chinese citizens had been issued with residence permits for educational purposes, about $32 \%$ of all Chinese immigrants in Germany. 
As education became the main channel of migration from China to Germany, it will be useful to note some features of this migration in the past decade. Demographically this is a relatively young community, with a high percentage of university graduates and a low percentage of thirdgeneration immigrants. Except for the immigrants in ethnic businesses, those in the main body of Chinese students and young professionals have few transnational ties, lacking relatives other than the nuclear family. With neither a family circle nor an ethnic neighbourhood, institutions like Chinese language schools or Chinese Christian churches have become important for Chinese immigrants, especially in socializing them into language and morality and transmitting Chinese heritage from one generation to the next.

The high percentage of students among Chinese immigrants in Germany translates directly into their participation in religious communities, including Chinese Christian churches. Oblau and Lüdde (Oblau 2006; Lüdde 2011) document the increasing proportion of students belonging to Chinese Protestant churches across the country since 2005, and how this demographic shift among church-goers has shaped these churches' profiles. However, at the CCCB the number of student attendees was gradually shrinking, being replaced by families and children as a significant part of the community. Back in 2003 the CCCB had fourteen Bible groups, six of which consisted entirely of students, and only one for 'jobholders' (上班族). In 2012, the CCCB had eleven Bible groups, only one of which was for students. Although there were students scattered among the other groups as well, most Bible Group Captains (查经小组 小组长) told me that they had mostly jobholders in the group.

In an article Pastor Xu posted on his blog on 25 March 2010, he proudly discussed the increasing number of families in the congregation, from only three when he first arrived in 2006 to a double-digit figure that was still rising year by year. Although unable to provide accurate statistics of the size of the congregation, all the Church committee members I talked to confirmed that the participation of families and jobholders had been growing fast. Throughout the years of my participant observation, the perceptible transformation of its sociological structure, and particularly the unseemly decline of students at the CCCB, caught my attention. How should we understand the increase in the number of families 
and the decrease in the number of students? When the number of students had been increasing and student churches had become the majority among Chinese Christian churches across Germany, why and how did the CCCB evolve differently? (cf. Kang 2021) And most importantly, what motivated Chinese migrant families to join the CCCB, and how did the CCCB manage to keep them coming and staying?

This chapter aims to answer these questions. Through an extensive two years of fieldwork, I examine the roles of Bible groups, Sunday school and Chinese language programmes both within and outside the church. I investigate the strategies of the church leadership and examine how the pastor and the Church committee have acted together to shift their focus from students to families in order to reach their goals.

\section{A 'natural environment' of Speaking Chinese}

When I first met David in 2014, he was five years old. Both his parents were ethnic Chinese who had first come to Germany around 2002 as students, had stayed and found jobs after graduation, and had been raising a family in Berlin with two adorable children. David was the younger child and had been born and raised in Berlin. He was in the last year of kindergarten when we met during a Sunday service at the CCCB. After a big smile and a cheerful 'Hallo' from him, I asked him in Chinese 'What's your name?' The smile disappeared, and the five-year-old suddenly put on a stern face, shook his head slowly and said to me 'Deutsch, bitte' ('German, please').

During my fieldwork at the CCCB, I never saw David speak Chinese. Whenever his parents talked to him in Chinese, David stared at his parents with his big beautiful eyes without saying a word. 'You have to be patient', said his father, summing up his approach. David responded only in German, when his parents finally ran out of patience and switched to German themselves.

This was why David's parents considered it necessary to take him to church every week. In the opinion of David's father, Mr Xie, the Chinese Christian Church of Berlin was the best place for guiding his children in learning and speaking Chinese, much better than any Chinese language 
school. 'There [at the language school] a teacher is teaching, children have to sit there and learn, it's all fake, and the children know that!' 'Fake?' 'Yes, fake! It is all arranged, not natural, and the children themselves know that. But here at church, this is a very natural environment [...] real and authentic. We are not pretending that we are teaching Chinese, we are all just speaking Chinese naturally: this is very real. Only here can children really be immersed in a Chinese environment.'

Ms Meng, mother of three children and a Sunday school teacher, agreed with $\mathrm{Mr}$ Xie completely. She had tried several Chinese language schools in the city before bringing her sons to the church. None of the schools worked very well for her boys, she explained, as they hated to 'go to school' at the weekend. 'Actually, the most important thing is not to have Chinese classes, but rather the Chinese environment! ... Think about how we grow up, right? Which one of us learnt Chinese during Chinese class at Chinese language school? It is the environment, after all!'

The unwritten goal of cultivating children's Chinese language skills had become a priority for the community organizers, and the parents spoke highly of the 'Chinese-ness' of the atmosphere in the CCCB and the Chinese-oriented events. The CCCB not only provided a Chinesespeaking environment, it also introduced Chinese traditions and customs into its community life. The major Chinese traditional festivals were elaborately planned and earnestly celebrated at the CCCB. Pastor Xu gave festive sermons, and church leaders offered special programmes echoing major Chinese holidays. The Church committee and all Bible Group captains organized grand entertainment shows and lavish banquets for the Spring Festival. In all these activities, the engagement of the children always played a prominent role.

The impact of this Chinese environment went beyond the activities during Sunday service. The parents I encountered at the CCCB all valued the potential circle of friends and the social life their children could cultivate during their participation at Sunday school and enthusiastically arranged play-dates and other get-togethers to strengthen their contacts and relations with Chinese friends. Quite frequently, the interest of the parents in the sermon did not seem to be as high as their interest in Sunday school. During every single service I attended over the years, there were often far more members gathered outside the Sunday school 
classrooms to chat with each other than members remaining seated in the main hall to listen to Pastor Xu preaching.

As Bourdieu points out, institutional experiences like schools draw children into transformative practices that go far beyond what they learn from textbooks in the classroom (Bourdieu 1984; Bourdieu and Passeron 1990). The impact of implicit socialization, where the transmission of principles, habitus and cultural capital takes place, could be far more effective and formative than the explicit socialization written in the textbooks (Bourdieu and Passeron 1990). While Bourdieu and Passeron criticized schools as institutions for the reproduction of legitimate cultures, the first-generation Chinese immigrants embraced institutions of this kind and believed in the impact of implicit socialization on the next generation. Those parents shared their faith in implicit socialization as a powerful medium for transmitting knowledge and competence and to transform the habitus and practices of the next generation.

Not surprisingly, the Sunday school teachers at the CCCB were asked to speak Chinese in the classroom, although it could be challenging to guarantee a Chinese-only classroom during Sunday school, as many young children had little knowledge of Chinese the language. 'At least we try to do that', one member of the Church committee told me. He also explained to me that speaking Chinese was the expectation of most members. Ms Zheng, one of the teachers in the class of six to eight years old, considered it important to 'set the rules straight' with the young pupils in her class and to make sure they were in a Chinese-speaking environment as long as they were in the church. 'We are the Chinese church. If we don't speak Chinese even here, where else?', Ms Zheng asked me rhetorically. But what if the children could not understand? 'We tell them some stories, but mainly do handiwork and drawings. [...] The children, of course, would still speak German among themselves, but we, their teachers and parents, have to set an example in speaking Chinese not only in the classroom but everywhere in the church and on Sunday afternoon.'

The CCCB provided Chinese immigrants in Berlin with a unique environment in which Chinese was the dominant language. Under the leadership of Pastor Xu and the Church committee, the CCCB was not only a place for 'getting to know God' and strengthening the Christian faith of Chinese immigrants in Berlin, but also a 'natural environment' in 
which the younger generation could speak and learn Chinese. Based on the growing number of families and the significant proportion of young children, this strategy proved very effective, and the CCCB became a popular place to go on a Sunday afternoon for Chinese immigrants.

The rise in the number of families attending was also reflected in the size of the Sunday school classes. In 2012, the CCCB had four classes for different age groups. Every class was taught and supervised by six to eight church members. This meant that among the 100 to 120 adults who attended Sunday service, about thirty of them were responsible for organizing and teaching Sunday school classes for the next generation. As the work of Sunday school became increasingly important, the Church committee decided to add a new 'Department of Children' to their agenda to hold weekly meetings to organize Sunday school and offer special events for the children during the school holidays. By providing an extensive programme for children, the CCCB was not only a place of worship, but also an additional school for second-generation Chinese immigrants in Berlin to learn the Chinese language and culture.

\section{‘Noah's Ark': A Bible Group Case Study}

It was Saturday. The CCCB's Bible group called 'Noah's Ark' (诺亚方舟) was meeting in the parish house of Trinity Church in Charlottenburg, in West Berlin for their Saturday gathering. The meeting began at 9:30 in the morning with a prayer. The group sang a few gospel songs together before they proceeded to the main session of Bible Reading, usually consisting of one or two paragraphs interwoven with discussions and personal testimonies. The entire 'Noah's Ark' groups consisted of about twenty adults and fifteen children, though the average turnout was usually twelve to fifteen adults and ten to twelve children.

'Noah's Ark' was only 500 metres away from Huade Chinese Language School (华德中文学校), the biggest Chinese language school in Berlin. 'Huade', literally meaning 'China and Germany', was founded in 1992 and attracted more than five hundred pupils every Saturday in 2016. As all the children in 'Noah's Ark' were attending Huade School at the same time, the Bible group's timetable was connected closely with the schedule 
of the Chinese language school. Every Saturday morning, the parents first brought their children to Huade School, where classes started at 9 a.m. While most parents gathered in the waiting room of the school to chat after the classes started, members of 'Noah's Ark' walked together to their Bible group meeting.

The Bible group meeting started at 9:30, its members being divided into two sub-groups. The 'upstairs group' used a small room with hardly any furniture besides a large table surrounded by chairs. The participants in this sub-group were mainly parents whose children were old enough to attend Huade School on their own. The 'downstairs group' used the biggest room in the parish house, with a large indoor playing area and plenty of toys, and a back door facing directly on to the outdoor playground in the back yard. All the adult participants in this 'downstairs group' had children who were too young to attend Huade School. These young children, sometimes even babies, played with each other in the corner with toys while their parents kept an eye on them during the Bible reading session.

Both 'Noah's Ark' sub-groups ended their sessions at 11:45 punctually. A few parents from the downstairs group would walk to Huade School to pick up all the children, whose classes at the language school ended at 12:00. The other members would come together, set up the table in the big room and prepare lunch. All the Chinese Christians in the CCCB who were members of 'Noah's Ark' referred to their common lunch as a 'Feast of Love'. Each member brought one or two dishes from home, all of which were placed on a long table to form a buffet, which was shared by all those present.

The Bible discussion might have its ups and downs, but the quality of this lunch buffet had always been superb. That Saturday when I attended was no exception. I picked my share of the buffet and sat down next to Mr Song. He stared at my plate of goodies, and asked: 'Do you know how to make a German potato salad?'

'You want German potato salad? Come on, look at these golden-brown coloured dumplings!' 'No, it's not for me! It's for my children!' Mr Song pointed to a young boy and a young girl playing board games with others at a kids' table. 'They don't like Chinese food so much; they like potato salad. Neither I nor my wife knows how to make it!' 
Mr Song and his wife were both born and raised in Fujian Province in southern China and came to Germany to study in 2000. On completing their education, they stayed in Germany and started a family there. When we met, Mr Song was working as a software engineer in a small town near Frankfurt am Main, while his wife and their children stayed in Berlin. 'Actually, we could have moved. My wife stays at home anyway. But we decided to keep the family here, and I commute every week. People all say that the schools in Hesse are actually better, but that town [where I work] is too small! No Chinese church, no [Chinese] Bible groups, let alone a Chinese language school! How can my children learn any Chinese there?' Mr Song drove at least five hours each way to commute, and I could almost see all the miles on his face as we were speaking. 'But it is not easy for my wife either. She has to take care of three children here, all by herself! Our youngest is only two years old!'

In spite of the hardships of taking care of three children by oneself, the exhaustion of driving more than five hours twice a week and the fact that the public schools in Hesse had a better reputation, Mr Song and his wife still preferred to keep the family in Berlin. The Chinese church, the Bible group and the Chinese language school were the reasons Mr Song gave me when I asked him for his reasons for staying in Berlin. His nine-yearold daughter, SS, walked around the buffet table as I was talking to her father. 'Look at her, she only has the face of a Chinese, everything inside is German!' commented Mr Song. 'All my kids are talking to each other in German; I and my wife sometimes don't know what they are talking about. I have to really catch up with my German to talk to them. [...] They play these German games, watch German TV, we don't know anything about it.'

SS's best friend, QQ, was the youngest daughter of Ms QD and $\mathrm{Mr}$ WG, both active members of 'Noah's Ark'. Just like Mr Song, QQ's parents were very pleased to find SS as a regular play date. 'They go to the language school together and sit in the same classroom', said Ms QD; 'here [pointing at the playground] they play together, and tomorrow [Sunday] they can be together at church for a whole afternoon'.

'It does not matter if they are speaking German among themselves; however, it matters that they make friends, make real Chinese friends', commented Mr WG, the father of QQ, when I asked him about the 
language QQ was using. 'Language learning has to happen naturally, you can't force them. We have three children, we both work, you just can't force things like this, you don't have the time! I say "Put on your shoes, you are late for school!": if it saves me time to tell them in German, then I will not speak Chinese, there is not so much to think about.'

Although Ms QD and Mr WG did not consider Chinese learning to be the main reason for taking her daughter to attend church activities, they were very proud to share QQ's improvement in Chinese language capacity. Ms QD enthusiastically told me that QQ could speak much better Chinese than her brothers. She was also able to write some Chinese characters, something none of her brothers was ever able to do. QQ recently started attending a Chinese calligraphy class at Huade School in the afternoon, which Ms QD was visibly very excited about. However, she did not forget to emphasize the importance of having her Chinese best friend, SS, who shared the credit for all the progress QQ was making: 'For children, it is important to have company, to do what their good friends are doing. If they don't have any Chinese friends, how can you convince them to go to Chinese classes?'

Pastor Xu praised 'Noah's Ark' constantly during Sunday services, as he considered it a great example of 'cultivating the heart and soul of our children'. He came to 'Feast of Love' to have lunch on Saturday from time to time and spoke highly of the combination of Bible reading and Chinese language learning. When asked further about the children who attended both Huade Chinese Language School and 'Noah's Ark' Bible group, Pastor $\mathrm{Xu}$ commented, 'Oh, they are the best! They go to Chinese school, sitting together with other children. Everyone sees immediately how great they are! [...] They are different from other children. ... Oh yes, completely different! They are the children of Christian parents, they are the children of our church, children of God, and they always behave much better than all other children do. Everyone can see and know right away what a great church we are.'

The combination of a Chinese language school and a Bible group meeting was the main attraction of 'Noah's Ark', and all the members scheduled their timetables to fit in accordingly. Starting at 9:30 and ending at 11:45, each session of Bible reading at 'Noah's Ark' lasted a maximum of two hours and a quarter, while other Bible groups usually had 
sessions of about four to five hours. When the Huade School was not open for classes during school breaks and holidays, the number of participants at 'Noah's Ark' declined simultaneously. This phenomenon again showed the importance of Chinese language learning for the members of the CCCB. For many first-generation Chinese immigrants, the Church had become one of the options for increasing the Chinese language abilities of their children. For the Church leaders, conversely, providing Sunday school and a Chinese-speaking environment had become an effective way of bringing in more families with children and thus building up a stronger community.

\section{The Superiority of Being a Christian}

Besides opportunities to improve the Chinese language skills of the younger generation, the $\mathrm{CCCB}$ offered Chinese immigrants more than regular Chinese language schools could: the teaching of Christianity. From Pastor Xu's sermons to Bible group discussions, CCCB members emphasized constantly and heavily the superiority of being Christians in general, and promoted the Church as a place for moral education for all its members.

At the CCCB, the positive impact of Christianity on the quality of family life was addressed publicly and frequently, reflecting a particular focus on families. Pastor $\mathrm{Xu}$, Church committee members and Bible Group captains often talked about the importance of choosing the 'correct spouse' (正确的配偶) for creating a 'sound family' (健全的家庭): in other words, choosing a Christian partner was the only way to have a good family life. Among the members of the CCCB, a 'Christian life' was understood not only as a way of leading a good life, it was also the definition of a good life. At all the baptism ceremonies I attended, when the newly baptized member stood up from the water after the full immersion, the crowd unanimously expressed their happiness by shouting, 'Now you can finally have a good life!'

This emphasis on a 'sound family' was passed on to the next generation as well. Preaching and teaching about how to lead a Christian life was a frequent theme at Sunday service and in Sunday school. For many parents, it 
was crucial to introduce their children to take part in more church activities to provide them with a sense of 'how other Chinese Christians live' and 'cultivate friendships with other Chinese Christian children'.

In Pastor Xu's sermons and in the CCCB's publications and materials, the superiority of being a Christian was repeatedly emphasized with pride. In the fundamental doctrine of the CCCB, 'The Basic Truth', this issue was verified by means of the following two arguments:

Only the Christian religion can show you the empty grave and tell you, the Savior has been resurrected from the dead. The ancestor of the Jewish people, Abraham, died around $1900 \mathrm{BC}$, and there was no resurrection. ... The founder of Buddhism, Gautama Buddha, also died. Muhammad died at the age of 62 in Medina [...]. But only Jesus Christ was resurrected from the dead and is still alive to this day, and that's why everyone who believes in him can live forever as well. [...] Besides, only Jesus Christ has claimed to the world that He is God, while none of the leaders of other religions has ever claimed himself to be God. Jesus Christ has the power to turn everyone to become Christians and to live as Christians, but other religions do not dare to say this. Other religions mostly talk about ethics, morality or goodness, but only Christianity can provide us with the power of the heart and soul, and turn everyone into a new person. ${ }^{3}$

Pastor $\mathrm{Xu}$ mentioned these points in his sermons frequently to remind all the brothers and sisters in the church to be 'confident about their choice to lead a better life'. This self-awareness of being 'better' was particularly visible during their missionary work: they approached nonChristian Chinese and asked questions like 'Are you happy?' and 'Do you have a meaningful life?' When the answers were 'Yes', they asked followup questions: 'How can you possibly be happy when you are not Christian?' and 'How can you have a meaningful life when you do not know God?' The missionaries at the CCCB often reminded one another to be 'friendly and polite, to show our Christian character', since in their opinion being 'friendly and polite' was a unique virtue that only Christians could possess.

Researchers have examined the impact of religions and religious communities on immigrants' experiences in a new society. For immigrant 
communities living in the US, it appears to be particularly urgent for parents to protect their children from the negative influences of their American peers and American culture, and many parents consider religious communities to be safe shelters (Suárez-Orozco and Suárez-Orozco 1995; Waters 2009). Asian immigrants in particular hold that public schools in the US do not offer any 'moral education' to their children, so they rely on religious communities for additional input. Zhou and Bankston (1998) show how Buddhist and Catholic institutions transmit the heritage of language and culture to the younger generation. Chen (2006, 2008) and Yang (2010) both describe how Christian churches become very attractive to Chinese immigrants by framing children's obedience to parents in Christian vocabulary and invoking the authority of Jesus Christ to discipline the younger generation.

Chen (2006) specifically analyses intergenerational conflicts among Chinese immigrants in the US. She argues that 'Confucian notions of filial obligation' are the key difference between the first and second generations. When the first generation can no longer use their Confucianbased parenting practices with their children, they turn to Evangelical Christianity for help. Johanna Lüdde (2011) makes a similar argument about Chinese students who have converted to Christianity in Germany. She considers the hierarchical structure of Chinese Christian churches and the emphasis on obedience and filial piety towards a 'Heavenly Father' to be the main attractions for young Chinese overseas, as they provide the 'Confucian traditions' that are familiar and trustworthy for the members to rely on.

Chen and Lüdde both refer to obedience and filial piety as Confucian traditions, although neither explains what Confucian traditions exactly are. In Chen's work, Christianity replaces Confucianism as a parenting tool, while in Lüdde's view, Christianity resembles Confucianism as a set of 'coping strategies'. In the case of the CCCB, narratives of 'obedience', 'duty' and 'humility' were indeed present, but Pastor Xu and the church leadership focused rather on the overall transformation of heart and soul as Christians. Instead of relying on being the elders for authority over against the younger generation, it was more important to embrace the Christian way of life being promoted at the CCCB, and to guide the 
younger generation on the right path through their regular participation in church activities.

The superiority of being a Christian convinced many parents that the church was the best place for children to grow up. 'Why should I send them to some language school when they can be in the house of God?' asked one parent, while chatting with me in the 'Martin Luther Room' during Pastor Xu's sermon. Besides wanting the younger generation to have a Chinese-speaking environment at weekends, the conviction that the church was 'a better place' and that Christians were 'better people' played an essential role in motivating the first-generation Chinese immigrants to bring their children to CCCB.

'More than two hundred Chinese gathering together is itself the best environment for children', said Ms Huang. She and her husband had been active members of the CCCB for almost ten years. Living on the outskirts of Berlin, the couple had to drive fifty minutes one way every Sunday afternoon to attend church services with their two children. When I asked her for her reasons, she summed up her belief in this way: 'Good values, good worldview, and orientation to spiritual life. Parents do not even need to guide their children to learn anything here, they are already surrounded by the best education, all in Chinese; they can just watch, hear, and learn. For a parent, there is no better place to bring your children to!'

\section{Conclusion}

Research on migrant religious communities in Germany frequently connects their religious practices with the question of integration. From Egyptian Christians to Buddhist Vietnamese, scholars have examined communities of various religious and ethnic backgrounds to analyse how their religious institutions have served as sites of communication, mediation and negotiation in order to integrate and assimilate these communities into German society (Baumann 2004; Währisch-Oblau 2005). There are also many works on Turkish immigrants and Islamic congregations (e.g. Fetzer and Soper 2005; Öztürk 2007; Ewing 2008). In contrast to the usual denunciations of Islamic beliefs potentially preventing Muslims 
from becoming 'proper' citizens in German civil society, research on Christian churches often addresses the positive impact of integration for immigrants in the country. Dümling argues that migrant Christian churches are 'the site of integration', and calls for more interaction between churches with migration backgrounds and churches without them, as she considers such encounters to be outstanding opportunities to 'shape integration' (Dümling 2011). Lüdde has taken a step further in her work with Chinese Christians. She identifies the 'inner psychological problems' of Chinese immigrants and argues that Chinese Christian churches in Germany could palliate them by offering 'coping strategies' and thereby smoothing the process of integration (Lüdde 2011, 2013).

As I have shown in this chapter, not only is 'integration' into German society not on the agenda of the CCCB, the Church leadership has instead been endeavouring to highlight its use of Chinese language and culture. This does not mean that the CCCB has necessarily obstructed the process of integration among its members, nor does it imply that its members have little willingness to integrate. Rather, the CCCB is one more example showing that the experience of being migrants in a diaspora can reinforce the sense of nationalist recognition, instead of encouraging a sense of world citizenship (van der Veer 1994). The CCCB keenly detected the 'faith' in implicit socialization among the first-generation Chinese parents, and designed their Church programmes accordingly to attract more members and multiply the size of their congregation and the Church's own income. Besides the emphasis on Chinese features, the pastor and the Church committee together structured the CCCB's teachings and activities around families. By offering a 'moral education' with 'good values' and 'a good world-view', the Chinese Christian Church in Berlin also provided Chinese immigrants with a space in which to construct shared codes of morality among themselves. In the words of Friedland, 'religion offers a nonessentialist basis upon which to construct a collective identity and difference' (Friedland 2002: 393), which is one format of religious nationalism.

Religious discourse and practice can be used for nationalist purposes, as well as provide a group with the cultural grammar and ritual repertoire to define its identity (van der Veer and Lehmann 1999). Although a Christian church strongly influenced by the Baptists might not have 
many roots in Chinese tradition, the CCCB has become an important venue for Chinese immigrants to locate their search for meaning and to strengthen their Chinese identity. Van der Veer points out that religious identity is not necessarily a matter of 'primordial attachments' inculcated by unchanging traditions, but 'specific products of changing forms of religious organization and communications' (van der Veer 1994: x). Throughout the trajectory of Chinese immigrants in Berlin, their shared challenges and aspirations have shaped their senses of longing and belonging, and have brought them together at the CCCB through their Christian faith. The combination of a Chinese-speaking environment and moral superiority makes the CCCB particularly attractive for families with children. This Church constitutes a unique community where language, culture, national identity and morality are intertwined with one another and where the religious institution has become 'an arena for sociality, collective organization and the provision of services outside state control' (Friedland 2002: 393). As I have shown in this chapter, the CCCB's leadership has made substantial efforts over the years to enhance the Chinese language capacity of second-generation Chinese immigrants and to create a space for them to amplify their moral orientation. These strategies, judging from the rocketing donations that have poured into the Church in recent years, were well received among Chinese migrant families in Berlin. The community as a whole utilized religious discourse and practice in order to shape a nationalist identity, an identity they wish to pass on from one generation to the next.

\section{Notes}

1. Unless indicated otherwise, quotations from informants are the author's translation from Chinese into English.

2. The number of members appearing on many of the CCCB's publicity materials is 'around 200'. In his blog of 25 March 2010, Pastor Xu stated that 'at the moment there are 250 adults and children' in the CCCB.

3. Original text from the Homepage of CCCB, 'The Basic Truth', http:// home.inter.net/immanuel/jbzl.htm (accessed 1 December 2018). Author's translation from Part 10 entitled 'Why is Christianity superior than other religions' (from Sect. 3, 'Religious Belief'). 


\section{References}

Baumann, Martin. 2004. Religion Und Ihre Bedeutung Für Migranten. Zeitschrift FürMissionswissenschaftund Religionswissenschaft 88 (3/4):250-263. Bourdieu, Pierre. 1984. Distinction: A Social Critique of the Judgement of Taste. Harvard University Press.

Bourdieu, Pierre, and Jean-Claude Passeron. 1990. Reproduction in Education, Society and Culture. 2nd ed. Reprint 2011. Sage.

Chen, Carolyn. 2006. From Filial Piety to Religious Piety: Evangelical Christianity Reconstructing Taiwanese Immigrant Families in the United States. International Migration Review 40 (3): 573-602.

. 2008. Getting Saved in America: Taiwanese Immigration and Religious Experience. Princeton University Press.

Dümling, Bianca. 2011. Migrationskirchen in Deutschland. In Orte Der Integration. Frankfurt Am Main: Lembeck.

Ewing, Katherine Pratt. 2008. Stolen Honor: Stigmatizing Muslim Men in Berlin. Stanford University Press.

Fetzer, Joel S., and J. Christopher Soper. 2005. Muslims and the State in Britain, France, and Germany. Cambridge University Press.

Friedland, Roger. 2002. Money, Sex, and God: The Erotic Logic of Religious Nationalism. Sociological Theory 20 (3): 381-425.

Kang, Jie. 2021. Chinese Christian Community in Germany. In Chinese Religions Going Global, ed. Nanlai Cao, Giuseppe Giordan, and Fenggang Yang, vol. 11, 97-114. Annual Review of the Sociology of Religion. Brill.

Lüdde, Johanna. 2011. Die Funktionen Der Konversion Chinesischer Studierender in Deutschland Zum Christentum (Protestantischer Prägung) Am Beispiel Einer Chinesischen Christlichen Gemeinde in Einer Deutschen Großstadt.

2013. Nur Eine Coping-Strategie Unter Vielen: Die Konversion Chinesischer Studierender in Deutschland Zum Christentum Evangelikaler Prägung. Zeitschrift Für Religionswissenschaft 21 (2): 145-176.

Oblau, Gotthard. 2006. Chinesische Studierende in Deutschland: Chancen Christlicher Begegnung. EMW.

- 2011. Chinese Christian Communities in Germany. Religions \& Christianity in Today's China 1 (2): 147-151.

Öztürk, Halit. 2007. Wege Zur Integration. Lebenswelten Muslimischer Jugendlicher in Deutschland. Bielefeld. 
Suárez-Orozco, Carola, and Marcelo M. Suárez-Orozco. 1995. Transformations: Immigration, Family Life, and Achievement Motivation Among Latino Adolescents. Stanford University Press.

Van der Veer, Peter, and Hartmut Lehmann. 1999. Introduction. In Nation and Religion: Perspectives on Europe and Asia, ed. Peter Van der Veer and Hartmut Lehmann, 3-15. Princeton: Princeton University Press.

- 1994. Religious Nationalism: Hindus and Muslims in India. University of California Press.

Währisch-Oblau, Claudia. 2005. Migrationskirchen in Deutschland. Überlegungen Zur Strukturierten Beschreibung Eines Komplexen Phänomens. Zeitschrift Für Mission 31: 19-39.

Waters, Mary C. 2009. Black Identities. Harvard University Press.

Yang, Fenggang. 2010. Chinese Christians in America: Conversion, Assimilation, and Adhesive Identities. Penn State Press.

Zhou, Min, and Carl Bankston. 1998. Growing up American: How Vietnamese Children Adapt to Life in the United States. Russell Sage Foundation.

Open Access This chapter is licensed under the terms of the Creative Commons Attribution 4.0 International License (http://creativecommons.org/licenses/ by/4.0/), which permits use, sharing, adaptation, distribution and reproduction in any medium or format, as long as you give appropriate credit to the original author(s) and the source, provide a link to the Creative Commons licence and indicate if changes were made.

The images or other third party material in this chapter are included in the chapter's Creative Commons licence, unless indicated otherwise in a credit line to the material. If material is not included in the chapter's Creative Commons licence and your intended use is not permitted by statutory regulation or exceeds the permitted use, you will need to obtain permission directly from the copyright holder.

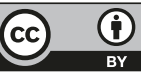

